\title{
The Development of Mathematics Interactive Comic for Third Grades of Elementary School
}

\author{
Ika Rahmawati \& Muhammad Wafiq Arzaaq Salam \\ Fakultas Ilmu Pendidikan Universitas Negeri Surabaya \\ Surabaya, Indonesia \\ ikarahmawati@unesa.ac.id \\ wafiq.getot@gmail.com
}

\begin{abstract}
In this study, researchers developed an interactive comic media learning mathematics material multiplication for the class III Primary School. The purpose of this study is to (1) describe the process of making interactive comic media, and (2) describe the validity of the interactive comic media. This research is a developmental study using a customized 4-D (four-D) development model. From the validation test results to the media expert, the interactive comics developed got a percentage value of $75 \%$. While the percentage value obtained from the material experts was $95 \%$. Data from the results of a limited trial conducted at two schools showed positive student's responses. This is indicated by the percentage value of each questionnaire item above $75 \%$. The conclusion of this research is the interactive comic media of learning mathematics of multiplication material for the third grade of elementary school developed is declared valid and feasible for use in learning.
\end{abstract}

Keywords—Media; interactive; comic; math; multiplication

\section{INTRODUCTION}

In running our daily lives, we will never escape from mathematics. Mathematics has an important role in helping people in their daily lives. Unfortunately, there is still an assumption that mathematics is merely a memorization of an agreed pattern. In fact, mathematics is not just about memorizing a pattern. More than that, it is a science that teaches the logical, critical and systematic thinking used to solve problems in everyday life precisely and practically [1]. With an agreement in mathematics, problems can be solved from simple to more complex problems quickly and precisely. Given the very important functions and benefits of mathematics, mathematics should be taught from an early age to children in order to be trained to think critical, logical and systematic in solving problems in everyday life.

One of the fundamental mathematical concepts is multiplication concept. Multiplication is the summation pattern of the same number consecutively in a certain number that is often used in mathematical operations. At elementary school level, multiplication is taught in class III which was previously introduced in class II. In general in the 2013 curriculum, Students study with accompanying student books as one of the learning resources. Primary school grade III students the curriculum elementary school 2013 is already equipped with image media to facilitate students to understand multiplication material. However, the third-grade student book is still considered to be inadequate. The limitations of the page make the explanation in the book less than the maximum, even the image media contained in it is also felt that it has not been able to become illuminated for the explanation contained in the book. This makes the students think that mathematics, especially multiplication materials, is a difficult, confusing and often unobtrusive lesson.

Therefore, it is necessary to develop instructional media which is not only able to be explanation about mathematics learning especially multiplication material, but the media used must be able to lead the opinion of students to form the assumption that mathematics learning especially multiplication material is not scary.

The selection of media development fell on the development of interactive comic media. Comics are very close to children, the majority of children love comics. So the comic has the potential to be developed into a fun learning medium so hopefully, children will feel happy and no longer experience fear when they learn math. Comics that will be developed into this medium is an interactive comic book that contains multiplication materials for elementary school children who are in class III.

The purpose of this research is to describe the process of making interactive comics media multiplication material for third grade students of Elementary School with media specifications in the form of A5 comic book print, The contents of the book using HVS paper and printed in color, equipped with instructions for the use of comics, cover using paper art paper and printed in color, The contents of the comic is a series of stories that contain multiplication material developed and adapted to complement the book of Primary Elementary school students, equipped with challenges in the form of puzzles arranged in the story related to multiplication material so that the comics become more interactive, characters used in comics are fictional characters ever made by previous researchers, The type of font used for comic contents is "steel city comic", there is a summary of the material on the back of the comic section, equipped with test skills test questions mapped into several a level, completed 
with an answer key placed on the final page to check the student's answer so students can learn independently as well as describing the validity of interactive comic material multiplication material for third-grade students of elementary school.

\section{METHODS}

In the study of Media Development of Interactive Comics Learning Mathematics of Multiplication Material For Grade III Primary School students, researchers use four-D research model (4D model) [2]. This research model is based on the Thiagarajan model which explains the development of detailed and systematic learning tools. Learning media is part of a learning tool, therefore the selection of Thiagarajan's research model is chosen because it is more appropriate and detailed in developing interactive comic media as part of the learning tool. This model is systematically designed to solve problems in a learning that has four stages in carrying out its development process. The stages are arranged in accordance with the characteristics of learning activities. This development involves the experts, so before the product of the research conducted field trials, the product has passed the revision phase based on the assessment results and input from experts.

The activity of the 4D (four-D) development model stage is described as follows: (1) Define; At this stage there are five phases: (a) (front-end analysis), in this phase will be analyzed the fundamental problems that occur in the field by making observations to several schools in Surabaya and surrounding areas related to the mathematics content, especially the elementary school multiplication materials; (b) (learner analysis), in this phase the researcher will interview the teacher and or student related to the level of understanding that the student has about the multiplication material in the content of the mathematics lesson; (c) (task analysis), in this phase the researchers process data from the results of preliminary observations that have been done before; (d) (concept analysis), in the next phase, the researchers analyze concepts that have been formulated and processed in the previous phases to be used in the design of interactive comic media; (e) (specification of objectives), at this stage will be formulated the specification of the purpose of Interactive Comic Media Development Learning Mathematics Material Multiplication For Students Class III Primary School. (2) Design; The next stage is design (design), in this stage there are four phases: (a) (criterion-test construction), in this phase researchers will arrange the criteria to be included in the interactive comic media; (b) (media selection), in this phase the researchers will formulate and select the appropriate story media to be developed into interactive comics for elementary school students keels III; (d) (Initial design), after the units needed to design the interactive comic media have been compiled from the previous phase, in the next phase the researcher begins to make the initial design of interactive comic multiplication material for the third grade of elementary school. (3) Develop; In the development phase, there are two phases: (a) (expert appraisal), is an assessment of some experts in the field about the design of comics that have been made before; (b) (developmental testing), after getting a review from the experts, the interactive comics that have been made are tested in a limited way at the school in the neighborhood around Surabaya. (4) Disseminate; In the last stage, there are three phases: (a) (effectiveness testing), after the product is tested, it will be analyzed its effectiveness; (b) (packaging), after the product is declared valid, then the product in the form of an interactive comic media is packed with an attractive appearance; (c) (diffusion and adaption), the last phase after the product is packaged is the spread and adjustment.[3]

The instruments used in this research are (1) media validation sheet to know the validity of the media made and the material validation sheet to know the validity of the material presented, (2) interview to know the responses, suggestions and comments on learning mathematics material multiplication, and (3) questionnaire given to students to know the response of users of interactive comic media. The questionnaire was given in the form of statements about the user's impression of the interactive comic media.

In this study the data obtained is qualitative data Qualitative data is processed using [4] analysis technique called flow model. Data processing techniques include: (1) Data reduction; is a data processing activity interview results are then selected and simplified from the overall data obtained. (2) Presentation of data; is an activity showing the results of data in the form of conclusions and decision-making actions that have been obtained in narrative so that it can be made an interpretation and evaluation. (3) Conclusion and verification; is an activity to give conclusions from the results of interpretation and evaluation. In this activity will be justified explanation and search the meaning of data.

Verification Activity is an activity to find the validity of a conclusion that has been obtained. Verification will test the correctness, conformity, and accuracy of data that has been obtained.

Data of validation of interactive comic media is done through validation activity done by 2 (two) validator. Validator will fill the validation sheet which then the value of each validator added and then converted into percentage of the average score of validation results

\section{RESULT AND DISCUSSION}

\section{A. Result}

This development research produced a learning media product in the form of an interactive comic book in book form printed with A5-sized paper developed with 4D (four-D) development model.

\section{A. Define}

There are several stages in this phase. The first stage is (a) (front-end analysis), at this stage, the researchers will analyze the problems that occur in the field by making observations. In the results of observations conducted at SDN Lakarsantri II Surabaya, researchers found a problem when the process of 
teaching and learning on the content of mathematics multiplication material. Students who initially look very excited are seen to turn into a lackluster.

Researchers also found that many students are still having trouble understanding the multiplication material. After doing the observation, the next step done by the researcher is (b) (learner analysis), in this phase the researcher interviews the student and teacher non-formally to identify the potential source of the existing problem more clearly. Interviews were conducted to classroom teachers and some students at two schools namely SDN Lakarsantri II and SDN Sambungrejo. From the results of interviews got some information that is (1) the teacher assumes that the students do not practice so that they are weak in the calculating skills. (2) Students are less interested in mathematics because they are confusing. (3) Students 'confusion is derived from the drawing media available in the students'. In addition to this information, researchers also get other information from the results of the interview that is (4) the majority of students love the comic.

The next step is (c) (task analysis), which is doing data analysis from result of observation and interview at SDN Lakarsantri II and SDN Sambungrejo. From the analysis of observation and interview data can be concluded that the problem faced by students is the fear of the multiplication material on the mathematical content derived from the inability of media images on the book used in helping explain the material to be learned so that students feel reluctant to learn and practice.

After the known problems that occur in the field, the next step is (d) (concept analysis), at this stage, the researchers formulate alternative options to overcome problems that have been found. Researchers chose to develop an interactive comic medium of multiplication mathematics learning material. The selection of comic media is based on observations and interviews conducted in the previous stage where an interview data was obtained which stated that the majority of children liked the comics. So that comics can be used as a media that leads students to assume the content that they will learn to be fun. The selection of characters in the comics to be developed falls on a fictional character named "output" ever made by previous researchers. The election is based on the acquisition of the best comic character nominations in 2015 awarded by the character, so it becomes a great consideration to develop it into a comic character that conveys the learning materials in hopes to attract the attention of the children so that the learning materials can be presented with ease and fun .[5]

The final stage in this phase is (e) (specification of objectives), in which the researcher formulates the purpose of developing the learning media of mathematics of multiplication material for the third grade of elementary school. The purpose of the development of mathematics learning materials multiplication media for class III Primary School is (1) to describe the process of making interactive comic media multiplication learning mathematics material and (2) to describe the validity of the comic and interactive media comic multiplication mathematics material multiplication.

B. Design
After all the steps in the Define phase are accomplished, the next phase is the design phase. In this phase, there are several steps that must be implemented (a) (criterion-test construction), at this stage the researchers prepare the needs and criteria to be included in the interactive comic media. Needs and criteria include multiplication material that will be delivered through the media to be developed and the basic skills that must be owned by students to be able to use the media to be developed. The material to be conveyed is the introduction of the concept of multiplication which is limited by multiplication of product times 3 (three) numbers. While the basic skills that must be owned by students is the ability to read. At this stage, the researcher also conducted a literature study on the topic of discussion in the development of interactive comic media learning mathematics material for class III primary school, the next stage is (b) (media selection), in this stage the researchers determine the media criteria to be used to develop. The choice falls on the form of an interactive comic print medium with A5 size which will contain a story capable of explaining the concept of multiplication. After the stages are passed then the last stage in the design phase is stage (d) (Initial design), in this stage will be made early draft of learning media in the form of interactive comics learning mathematics material multiplication for class III Primary School

For the early stages of interactive comic design, begins with creating interactive concepts in print. Thus allowing the reader to interact in comics as the final determinant of the story while still understanding the multiplication material.

Preparation of the story framework is done at this stage. Begin by creating a story framework and inserted multiplication material to be delivered. Starting from the creation of synopsis and logline of the synopsis and logline are made into a rough frame of interactive comics in printed and paneled form.

Thumbnail is used as a baseline to make pages in final form. The process is scanning rough sketches in digital form. After the image is scanned entirely, then the image will be processed to be trimmed its lines. This process is called Tracing / Lining.

Tracing and lining is done using bitmap-based image editing software. After all the images are traced and neatly dotted then the next process is coloring. Coloring uses the same software as the plagiarism process. Before coloring, color selection is done first as the identity of each character and the consistency of the place background.

When the colors have been selected, the next process is coloring the comic images that have been neat. The color used is the color contained in the color box that has been prepared before. After the image has been colored, the next step is giving text on each word bubble with the same image processing application as the previous step. After all the designs of each page are colored and texted, the next step is the preparation and adjustment to be a printed book. The preparation of the content and materials in the comic is done using the help of software for lay outing. Content formats, page numbering and layout are set in this step. In this step you will check the flow of the interactive comic for easy and convenient read when printed. For the sake of comfort in reading, the odd page layout is even set in this step so that when comics are 
printed, comics can be easily understood and comfortable when read.

In this process, there is often a difference between the initial draft designs. Generally, the addition or reduction of some pages to maximize the message or material submitted by the comic to the reader.

After all is neatly arranged then the file is stored in PDF format. The next step is to design a cover page. With the same stages as when creating content pages. After all is neatly arranged then the file set will be submitted to the printing press for printing.

\section{Develop}

In the develop phase, there are several stages passed by the researcher. The first phase in this phase is (a) (expert appraisal) where in this stage the researchers work with experts to test the validity of the developed interactive comic media. In this phase, the researcher cooperates with two experts, the material expert to know the validity of multiplication learning material in the comic media and the comic media experts to know the validity of the comic media in conveying the message.[6]

From the data obtained on the validation sheet on the multiplication material in the interactive comics obtained a total value of 46 out of 48 total value of the whole. So that can be obtained Percentage score validation results of $95 \%$

Because the acquisition Percentage score of validation results $95 \%$, then the material in the comic media interactive learning mathematics material multiplication for class III primary school can be said to be valid from the material side delivered in the comic.

From the results of data obtained on the validation sheet of interactive comic media obtained a total score of 36 out of 48 total value of the whole. So that can be obtained Percentage of validation score of $75 \%$

Because of the percentage of scoring results $75 \%$ validation, then the interactive comic media learning mathematics material multiplication for class III primary school can be said to be valid in terms of media.

From the results of the percentage acquisition of both experts both material experts and media experts produce a fairly high value of $95 \%$ and $75 \%$ so it can be concluded that the interactive comic media learning mathematics material multiplication for class III primary school declared valid.

In the validation process, there are some inputs from experts both material and media experts for revision.

\section{Dissemination}

The last phase in this research development model is the dissemination phase. In this phase there are several stages, namely (a) (effectiveness testing) where valid product will be tested in limited to two schools namely SDN Lakarsantri II Surabaya and SDN Sambungrejo to know the response and response from the user. In the limited trial process found positive results from the limited trial respondents. Researchers found the fact that children are very enthusiastic about comics especially learning comics. In a limited trial process, the children look very excited when they learn to learn by using comics.

To know more clearly about the user's response, the researchers distributed questionnaires to 20 students for SDN Lakarsantri II and 20 sheets for SDN Sambungrejo. In a questionnaire distributed there are 11 statements filled by students.

From the data, it can be seen that each point of the assessment statement gets a score above $75 \%$ so it can be concluded that the comic interactive media of learning mathematics of multiplication material is declared feasible and get good response from the user in the limited trial that has been done. After the trial process is limited, the next process is (b) (packaging), product packaging is only done with the addition of clear plastic to protect the comic book print and still display the appeal of the cover.

At the last stage of this phase (c) (diffusion and adaption) is not done by the researcher. This is because the purpose of the research has been done without having to do that stage. This stage will remain outside of this study.

\section{B. Discussion}

When the interactive comic development results from this study were tested, the students were able to understand the story content and the majority of the children understood the content of the message (material) delivered in the comic. This is because the comics of the development have images that support the explanation of the writing submitted. Thus, grade 3 primary school children whose average age is 9 (nine) years old, can easily understand the intent of the message or material submitted by the comic. In accordance with Piaget and Bruner's theory that children between the ages of 7 and 11 are included in the semi-abstract category (Piaget) or iconic (Bruner) which allows them to think logically about concrete events that are depicted with images on comics so that in using interactive comic development results are not found a significant constraint to be able to understand the content in the comic.

At the time the researchers conducted observations on the comics tested, the majority of new children can work on the questions in the book with the help of seeing the information in the comic first. In accordance with the ZPD theory of Vygotsky, this proves that the language in the comic plays an important role in helping students to be able to do the problem.

The enthusiasm of the students in the trial is limited in accordance with the opinions expressed by [5]that comics are suitable for learning because the comics are in demand by students. Students are seen enjoying in reading comics. Every now and then they smile and even laugh when they enter the funny elements presented in comics caused by stories and pictures that are on the comic.

In line with the opinion of [7]which states that the media have a facilitative feature that can move students emotionally to be more comfortable and comfortable in learning, when performing limited test, effective function on developed 
comics media is seen clearly. The effective function of the media in the visual media can help the teacher in generating the emotions and behaviors of the students to be able to learn comfortably and happily.

In addition to effective functions, the main function of a media as a learning resource can also be seen in limited trials. At the time students do the problem, seen some children open comics back to remember the steps in operating the number of two-digit results.

This proves that the comics of development have already characterized as learning media in accordance with the opinion of [8]). At the time of limited trials in SDN Lakarsantri II researchers also found some children who are still difficult to read. However, when the child takes a look at the comic book image, the child gradually grasp some parts of the comic so as to encourage the child to continue to understand what is in the comic either by reading his writings or by understanding the images present in each panel in the comic. The discovery is in accordance with the opinion [9] which states that comics can help visualize the imagination of children who are still difficult to read.

\section{CONCLUSION}

From the results and discussion of the study of the development of interactive comic media learning mathematics material multiplication for the class III primary school obtained a conclusion that the interactive comic media learning mathematics material multiplication for class III Primary School created and developed with 4D (four-D model) worthy of use in learning. This is evidenced by the positive response of the limited test results that get an average score of $84 \%$. As well as the validity score of the experts who scored $95 \%$ percentage for material experts and $75 \%$ for media experts.

After the text edit has been completed, the paper is ready for the template. Duplicate the template file by using the Save As command, and use the naming convention prescribed by your conference for the name of your paper. In this newly created file, highlight all of the contents and import your prepared text file. You are now ready to style your paper; use the scroll down the window on the left of the MS Word Formatting toolbar.

\section{REFERENCES}

[1] T. Rattanatumma and V. Puncreobutr, "Assessing the Effectiveness of STAD Model and Problem Based Learning in Mathematics Learning Achievement and Problem Solving Ability.,"J. Educ. Pract., vol. 7, no. 12, pp. 194-199, 2016.

[2] A. Shoimin, "model pembelajaran inovatif dalam kurikulum 2013." Yogyakarta: Ar-Ruzz Media, 68AD.

[3] J. Santrock, "Life-span Development Perkembangan Hidup Jilid 1 Edisi Kelima," Jakarta: Erlangga, 2002.

[4] H. P. Setyosari, Metode penelitian pendidikan \& pengembangan. Prenada Media, 2016

[5] A. Lamb and L. Johnson, "graphic novels, digital comics, and technology-enhanced learning: part 1," Teach. Libr., vol. 36, no. 5, p. 70, 2009 .

[6] I. Rifa, "Koleksi Games Edukatif di Dalam dan Luar Sekolah," Yogyakarta: Flash Books, 2012.

[7] D. D. Deiters, S. Stevens, C. Hermann, and A. L. Gerlach, "Internal and external attention in speech anxiety," J. Behav. Ther. Exp. Psychiatry, vol. 44, no. 2, pp. 143-149, 2013.

[8] A. Arsyad, "Media pembelajaran." Jakarta: PT Raja Grafindo Persada, 2011.

[9] E. Mulyasa, "Kurikulum tingkat satuan pendidikan sebuah panduan praktis," Bandung PT Remaja Rosdakarya, 2007. 